\title{
ПРАВОВА ПРИРОДА
}

ТА ЗМІСТ МІЖННАРОДНИХ ВИБОРЧИХ СТАНДАРТІВ

\section{ЮРІЙ КЛЮЧКОВСьКИЙ}

/ кандидат фіз.-мат. наук, доцент кафедри загальнотеоретичного правознавства і публічного права Національного університету «Києво-Могилянська академія»

\section{ABSTRACT}

The paper deals with international electoral standards as a particular case of a general category of international legal standards, historically first example of which being international human rights standards.

International legal standards are fixed in two types of instruments, namely, international treaties which are to be ratified (obligatory instruments) and documents of international organizations ("soft law" acts). The case-law of international courts, first of all of European Court of human rights, is very important, too. Obligatory provisions expressing standards are principles of a corresponding branch of national (not international) law; they are formulated in the most abstract way as a "principle-name".

The ways of international standards implementation into national legal system are considered especially via legislation, law enforcement as well as via direct using by all subjects of corresponding legal relations.

The system of main international electoral standards is formulated (as "principles-names") which includes principles of direct and periodical elections, universal and equal suffrage,

free, fair and genuine elections, secret and personal voting as well as a demand of stability of electoral legislation Key words: international electoral standards, international legal standards, principle of law, "soft law", binding standard, recommendation standard, implementation of international standards.

\section{АНОТАЦІЯ}

Стаття присвячена розгляду міжнародних виборчих стандартів як часткового випадку загальної категорії міжнародних правових стандартів, історично першим зразком яких є міжнародні стандарти у сфері прав людини. Міжнародні правові стандарти фіксуються в актах двох типів - міжнародних договорах, що підлягають ратифікації (зобов'язальні акти), та актах міжнародних організацій (актах «м'якого права»).

Важливу роль відіграє також практика міжнародних судів, насамперед Європейського суду з прав людини. Зобов'язальні положення, що виражають стандарти, є принципами відповідної галузі національного (а не міжнародного) права і сформульовані максимально абстрактно у вигляді «принципів-назв».

Розглянуто шляхи імплементації міжнародних стандартів у національну систему права - законодавчий, правозастосовний, а також через їх безпосереднє застосування усіма суб'єктами відповідних правовідносин.

Сформульовано систему основних міжнародних виборчих стандартів (у вигляді «принципів-назв»), яка включає принципи: прямих, періодичних виборів, загального і рівного виборчого права, вільних чесних та справжніх виборів, таємного та особистого голосування, а також вимогу стабільності виборчого законодавства.

Ключові слова: міжнародні виборчі стандарти, міжнародні правові стандарти, принцип права, «м'яке право», обов'язковий стандарт, рекомендаційний стандарт, імплементація міжнародних стандартів. 
Me іжнародно-правові стандарти у сфері виборів є складовою загальної категорії міжнародних стандартів, яскравим прикладом впливу міжнародно-правового регулювання на одну із важливих галузей національного конституційного права виборче право. Однак міжнародні виборчі стандарти як інститут міжнародного права — їх значення для національного виборчого права все ще недостатньо вивчені. Не існує єдиної точки зору щодо правової природи цих стандартів, їх місця у системі виборчого права. Цим обгрунтовується актуальність дослідження цієї проблеми.

Міжнародні правові стандарти - відносно нове правове явище, що сформувалося після Другої світової війни. Його розглядають у контексті процесів правової глобалізації (див., наприклад, [1, с. 11; 2, с. 47]).На думку болгарського правознавця $€$. Танчева, «міжнародно-правові стандарти... $\epsilon$ зв'язуючою ланкою між національним і глобальним конституціоналізмом» [3, p. 31].

Права людини стали першою сферою регулювання, для якої були розроблені загальноприйняті міжнародні правові стандарти і в якій «переплелися» міжнародно-правові норми і національне право. За П. Рабіновичем, «першою ознакою... стандартів зазвичай називають фіксацію а) певного змісту, чи б) певного обсягу, чи в) водночас і змісту, й обсягу прав людини. Ці стандарти становлять закріплені у міжнародних актах та інших міжнародних документах ті «праволюдинні» показники, до досягнення яких зобов'язуються або заохочуються держави» [4].

Міжнародні стандарти у сфері прав людини стали зразком і джерелом формування й поширення міжнародних правових стандартів в інших сферах. Такі визнані стандарти сьогодні існують стосовно інших галузей права чи правових інститутів, що належать до національного права, - місцевого самоврядування, політичних партій, судочинства, у сферах охорони довкілля та протидії корупції та інших. Науковці зазначають, що сьогодні «важко уявити будь-яку сферу, у якій би не існувало загальновизнаних міжнародних стандартів» [5, с. 407].
У цьому переліку важливе місце займають і міжнародні виборчі стандарти. У своєму становленні і розвитку практично усі існуючі міжнародні стандарти різних сфер (галузей) права історично походять від стандартів прав людини, часто зберігаючи у тій чи іншій формі такий зв'язок (у тому числі через міжнародно-правові акти, у яких вони закріплені), однак за своїм змістом і спрямуванням вони виходять далеко за межі цієї сфери.

Уявлення про те, що закріплені у міжнародному праві виборчі стандарти є складовою стандартів прав людини, розповсюджене. Зокрема, М. Баймуратов та Б. Кофман, розглядаючи міжнародні виборчі стандарти, виходять із позиції, що «мегаметою та мегатрендом виборів... $є$ дотримання прав і свобод людини і громадянина» [6, с. 55].

Не можна заперечувати як джерельного, так і певного змістовного зв'язку міжнародних виборчих стандартів з міжнародними стандартами прав людини. Бачення суті правової основи виборів як дотримання специфічних виборчих прав громадян досить поширене ${ }^{1}$. Звичайно, демократичні вибори передбачають належну реалізацію виборчих прав громадян. Хоча перші міжнародні виборчі стандарти були сформульовані у міжнародно-правових актах, присвячених правам людини, однак і ці положення мають зміст, який виходить за межі «людиноправного» контексту.

Роль системи міжнародних виборчих стандартів значно ширша, аніж забезпечення виборчих прав громадян. Вибори слід розглядати не лише як сферу реалізації прав і свобод людини, а передусім як суспільно-політичний інститут, який визначає формування складу органів влади демократичної держави. Вибори $є$ способом реалізації народного суверенітету, коли основним суб'єктом виступає не так окрема людина, як народ, і не так у руссоїстському сенсі (як проста сукупність громадян), а як колективний, проте цілісний суб’єкт. Тому вибори слід розглядати як базовий інститут демократичного державного режиму. Це виводить нас поза сферу прав людини і дає підстави стверджувати, що демократія $є$ самостійною цінністю, яка не перебуває

\footnotetext{
1 Принагідно звернемо увагу, що воно знайшло своє відображення у структурі Особливої частини Кримінального кодексу України, де виборчі злочини віднесені до Розділу V «Злочини проти виборчих, трудових та інших особистих прав і свобод людини і громадянина»; у такий спосіб безпідставно обмежується розуміння сутності виборчих злочинів, ступінь їх суспільної небезпеки. Низка виборчих злочинів, передбачених Кримінальним кодексом, стосуються порушення не стільки власне суб'єктивних виборчих прав, скільки правомірного порядку проведення виборів, а значить, порушення конституційного принципу народовладдя. У цьому контексті звернемо увагу, що склади менш суспільно небезпечних виборчих правопорушень віднесені до глави 15-А Кодексу України про адміністративні правопорушення, і кваліфікуються як такі, що «посягають на здійснення народного волевиявлення та встановлений порядок його забезпечення»; вважаємо, що така кваліфікація більш адекватно відображає об'єкт виборчих правопорушень, не зводячи його лише до виборчих прав громадян.
} 
у генетичному зв'язку (хоча й пов'язана у сфері їі реалізації) з іншою цінністю - правами і свободами людини. Зрештою, третьою такою цінністю, яка не походить з перших двох (як і перші дві не зводяться до неї), але пов'язана з ними, є верховенство права. У зв'язку з цим нагадаємо, що Статут Ради Європи передбачає три окремі ціннісні (ідеологічні) «опори» - демократію, верховенство права і права людини [7] (див. також [8, р. 4]). Це дозволяє стверджувати, що демократія, центральним інститутом якої $є$ вибори, разом із правами людини і верховенством права $є$ тією сферою, де утворення цивілізаційної єдності держав і націй, заснованої на спільній системі цінностей, має наслідком формування спільних для них (а отже, міжнародних) систем правових стандартів - цивілізаційних принципів права [9], які виражають ці цінності. Саме цим, а не генетичним зв'язком із правами людини, можна пояснити формування розвинутого масиву міжнародних виборчих стандартів, які разом із фундаментальною вимогою, щоб державна влада була заснована на волі народу, визначають суть демократичних виборів.

Визнаючи існування загальної тенденції «конституціоналізації міжнародного правопорядку та інтернаціоналізації національного конституційного права» [6, с. 54], стверджуємо, що предметом міжнародних виборчих стандартів $\epsilon$ насамперед загальні засади регулювання виборів як способу реалізації суверенітету народу і формування органів влади у демократичній державі з дотриманням спільних цивілізаційних цінностей. Існування розвинутої системи виборчих стандартів для багатьох держав дозволяє говорити про формування спільного (значною мірою однакового) для цих держав виборчого права, заснованого на єдиній системі принципів-стандартів.

Виборчі стандарти, встановлені першим із міжнародно-правових актів у цій сфері - Загальною декларацією прав людини 1948 р. - проголошують: «Воля народу повинна бути основою влади уряду; ця воля повинна виявлятися у періодичних і справжніх ${ }^{2}$ виборах, які повинні провадитись при загальному і рівному виборчому праві шляхом таємного голосування або ж через інші рівнозначні форми, що забезпечують свободу голосування» (див. статтю 21) [10]. Сформульовані тут положення $\epsilon$ фактично максимально абстрактно вираженими принципами виборчого права. Уважний аналіз змісту цитованого положення засвідчує, що власне виборчих прав громадян стосуються вимоги загального і рівного виборчого права і певною мірою свободи голосування. Водночас вимоги періодичних і справжніх виборів, таємного голосування, як і загальна вимога щодо волі народу, яка повинна лежати в основі влади в державі, стосуються інших аспектів виборів і навіть більш загально - представницької демократії як державного режиму.

Аналогічні за змістом виборчі стандарти містяться у статті 25 Міжнародного пакту про громадянські і політичні права 1966 р. [12], яка повторює усі принципи виборчого права, закріплені Загальною декларацією прав людини, - як ті, що стосуються виборчих прав громадян, так і принципи справжніх та періодичних виборів і таємного голосування.

Ще далі від безпосереднього контексту прав людини відходить виборчий стандарт, встановлений статтею 3 Першого протоколу (1950р.) до Конвенції про захист прав людини і основоположних свобод, який проголошує: «Високі Договірні Сторони зобов'язуються проводити вільні вибори з розумною періодичністю шляхом таємного голосування в умовах, які забезпечують вільне вираження думки народу у виборі законодавчого органу» [14]. Наведене формулювання насправді містить загальні вимоги щодо виборів і дуже далеке від прямого ствердження конкретних прав людини чи громадянина. Європейський суд з прав людини, правові позиції якого надають тлумачення положенням Конвенції та протоколів до неї, у

\footnotetext{
${ }^{2}$ В українському (неофіційному) перекладі Декларації, розміщеному у базі даних законодавства на сайті Верховної Ради України [10], вжито термін «нефальсифіковані вибори». Проте в англійськомуоригіналі Деклараціївикористано термін «gепиіпе еlections», що перекладається як «справжні вибори». Відповідний російський термін («подлинные выборы») вжитий, зокрема, при посиланні на Загальну декларацію прав людини у Резолюції Генеральної Асамблеї ООН «Підвищення ефективності принципу періодичних і справжніх виборів» від 17 грудня 1991 року [11]. Цей же термін («справжні вибори») містить український переклад статті 25 Міжнародного пакту про громадянські і політичні права [12], в англійському оригіналі якого вжито термін «gепиіпе еlections». Таке розуміння підтверджується поєднанням термінів «genuine, free and fair election» — «справжні, вільні і чесні (нефальсифіковані) вибори», що міститься в іншому документі - Деклараціі Міжпарламентського союзу про критерії вільних і чесних виборів [13], яка посилається на Загальну декларацію прав людини. Поняття «справжні вибори» сьогодні прийнято інтерпретувати як «вибори з наявним вибором» на відміну від «виборів без вибору», характерних для радянського режиму. Враховуючи час прийняття Загальної декларації прав людини (1948 рік), вважаємо, що розуміння терміна "genuine elections» як вимоги «справжніх виборів», «виборів з вибором», адекватніше.
} 
контексті статті 3 Першого протоколу запровадив дещо евфемічне поняття «права на вільні вибори», не конкретизуючи його суб'єкта (таким суб'єктом фактично може бути суверенний народ, а не окремий громадянин). Суд вважає, що індивідуальні виборчі права закріплені у цитованому положенні у неявному вигляді, і розглядає їх у дещо відмінний спосіб порівняно з іншими правами, проголошеними і захищеними Конвенцією. Так, у справі «Матьє-Моен та Клерфе проти Бельгії» (1987 р.), одній із перших справ щодо статті 3 Першого протоколу, Суд підкреслив, що виборчі права не є абсолютними і можуть підлягати обмеженням, встановленим державою, якщо такі умови не перешкоджають «вільному вираженню думки народу у виборі законодавчого органу» [15]; цим, по суті, стверджується, що у сфері виборів права народу мають перевагу перед індивідуальними правами громадян.

Міжнародний пакт про громадянські та політичні права, Перший протокол до Конвенції про захист прав людини і основоположних свобод $\epsilon$ основними зобов'язальними документами, які встановлюють міжнародні (європейські) виборчі стандарти. Інші зобов'язальні документи, які часто згадуються у контексті міжнародних виборчих стандартів - Конвенція про політичні права жінок 1952 р., Конвенція про ліквідацію всіх форм дискримінації щодо жінок 1979 р., Міжнародна конвенція про ліквідацію всіх форм расової дискримінації 1965 р. - не містять принципово нових положень ${ }^{3}$ порівняно із стандартами, встановленими зазначеними вище документами. Аналогічні виборчі стандарти для місцевих виборів встановлені статтею 3 Європейської хартії місцевого самоврядування [16], на що нечасто звертають увагу дослідники.

Міжнародні правові стандарти як правова категорія. Незважаючи на безсумнівність існування і загальне визнання важливої ролі міжнародних виборчих (i, більш загально, правових) стандартів, можна говорити про різні підходи до їх розуміння. Зазвичай вважається, що стандарт $\epsilon$ певним зразком, еталоном. Є. Танчев підкреслює: «Термін «стандарт» слід розуміти як «настанова для поведінки та для оцінки поведінки»... Поняття міжнародних стандартів позначає деякі універ-

\footnotetext{
3 Положення цих документів, які стосуються виборів, присвячені конкретизації вимоги рівності виборчих прав стосовно окремих категорій громадян.
}

сальні, загальноприйняті канони поведінки держав, корпорацій та індивідів» [3, p. 24].

Дослідники часто розглядають міжнародні правові стандарти як норми і принципи міжнародного права. Таке розуміння поширюється і на виборчі стандарти. Так, М. Баймуратов і Б. Кофман, приймаючи визначення міжнародних виборчих стандартів як принципів міжнародного права [6, c. 3], водночас розглядають ці ж стандарти як сукупність «правових норм (матеріальних та процесуальних, технологічних /технічних) і нормативних вимог, що мають різну правову силу (загальнообов'язкові, рекомендаційні)» [6, с. 51], що не може бути охоплене лише поняттям «принципи міжнародного права».

Вважаємо, що найпродуктивнішим $\epsilon$ розуміння міжнародних виборчих стандартів як галузевих принципів права. Незважаючи на те, що вони закріплені у міжнародно-правових документах, їх зміст і спрямованість змушує визнати їх галузевими принципами не міжнародного, а національного (внутрішнього) виборчого права, хоча й спільними для низки країн. Уважний погляд на предмет відповідного правового регулювання засвідчує, що зазначені принципи мають міжнародно-правовий характер тільки за формою (способом вираження) - через міжнародні договори або документи міжнародних організацій. За своїм змістом ці стандарти повинні входити до системи вихідних положень (галузевих принципів), на яких будується національне виборче право.

Зазначене розмаїття у розумінні сутності міжнародних (у тому числі виборчих) стандартів засвідчує недостатнє вивчення цього правового явища. По суті, різні визначення часто стосуються різних за правовими особливостями міжнародних стандартів. Такі розбіжності у їх розумінні мають об'єктивну причину: надзвичайно широкий обсяг масиву міжнародних стандартів містить положення різної правової природи і, як наслідок, різного змістовного прояву з точки зору способу регулювання. Ці факти ставлять проблему систематизації (класифікації) міжнародних правових стандартів.

Найбільш очевидним (після класифікації за сферами регулювання) $\epsilon$ поділ усього масиву міжнародних правових стандартів на універсальні (глобальні, адресовані усім державам світу) та регіональні (спрямовані до держав певного географічного регіону - європейські, латиноамериканські, арабські, африканські) [5, с. 406; 17, с. 39-40]. 
Універсальні і регіональні міжнародні стандарти дещо відрізняються своїм змістом. Справедливим $є$ спостереження, що перші виступають як більш загальні, абстрактніше сформульовані положення, оскільки повинні бути адресовані усім державам - членам міжнародної спільноти, які належать до різних правових сімей та характеризуються різними правовими системами. У цьому сенсі універсальні міжнародні стандарти можуть розглядатися як відображення загальносвітових суспільних цінностей, спільних для більшості (якщо не усіх) держав світу, а тому вони, як правило, за своєю суттю відіграють роль універсальних (як загальних, так і галузевих) принципів права. Регіональні стандарти адресовані вужчому колу держав, здебільшого споріднених цивілізаційно або сім'ями систем права; тому вони, відображаючи цивілізаційні чи правосімейні цінності [9], як правило, ширші за змістом і включають не лише принципи права, але й більш конкретні положення. Класичним прикладом у цьому сенсі виступають європейські правові стандарти. Є. Танчев підкреслює: «Усі стандарти мають корені у демократичному конституційному розвитку, а європейські стандарти випливають із спільного європейського доробку» [3, p. 25].

Зв'язок міжнародних правових стандартів (як універсальних, так і особливо регіональних) із спільними суспільними цінностями опосередковується інституційно у сенсі міжнародних інституцій - міжнародних організацій відповідного рівня. Так, джерелами універсальних правових стандартів $\epsilon$, в основному, документи ООН (у тому числі багатосторонні міжнародні договори), зрідка - інших організацій, як, наприклад, Міжпарламентський союз чи Міжнародна організація праці. Європейські правові стандарти значною мірою завдячують діяльності Ради Європи та її органів; це відповідає цілям, зафіксованим у статті 1 Статуту Ради Європи: «більшого єднання між їі членами для збереження та втілення в життя ідеалів і принципів, які $\epsilon$ їхнім спільним доробком..., в економічній, соціальній, культурній, науковій, правовій та адміністративній сферах, а також збереження і подальшого здійснення прав людини і основних свобод» ${ }^{4}$ [7]. Іншою міжнародною інституцією, яка відіграє важливу роль для формулювання міжнародних правових стандартів, $\epsilon$ Організація з безпеки і співробітництва в Європі (ОБСЄ). У цьому випадку певною мірою можна говорити про цивілізаційний (у сенсі західної, євроатлантичної цивілізації) характер відповідних стандартів. Однак принципової відмінності між виборчими стандартами, встановленими документами Ради Європи та ОБСЄ, не існує.

Правова природа і роль міжнародних стандартів, їх вплив на регулювання відповідних правовідносин істотно залежать від типу міжнародно-правових актів, якими вони встановлені. Такі стандарти містяться як у міжнародних (багатосторонніх) договорах, так і в актах (резолюціях, рекомендаціях, деклараціях, коментарях) міжнародних міжурядових організацій, рішеннях (правових позиціях) міжнародних судових установ. Це стосується не лише найбільш розвинутої системи стандартів у сфері прав людини, але й усієї категорії міжнародних правових стандартів. Відповідно існують два види правових положень, в яких фіксуються стандарти, - зобов'язальні та рекомендаційні («авторитетні»). Зобов'язальні міжнародно-правові стандарти закріплені багатосторонніми міжнародними договорами i, в силу загальноприйнятих принципів міжнародного права, $€$ обов'язковими для дотримання державами - учасниками відповідного договору. Класичними прикладами міжнародних документів, що містять зобов'язальні для України міжнародно-правові стандарти у сфері виборів, $є$ згадані вище основні документи, що стосуються прав людини Міжнародний пакт про громадянські та політичні права та Конвенція про захист прав людини і основоположних свобод разом із Першим протоколом і низкою інших протоколів.

Зобов'язальні положення, що виражають стандарти, достатньо загальні й найчастіше формулюються як абстрактні принципи («принципиназви»; див. [18, с. 64]). Будучи положеннями, сформульованими в актах міжнародного права, вони все ж не $\epsilon$ типовими принципами міжнародного права, оскільки не регулюють міжнародні відносини. Такі стандарти-принципи функціонують на межі міжнародного і національного (внутрішньодержавного) права та забезпечують «доместикацію» відповідних міжнародно-правових норм, що стосуються національного права. Дійсно, хоча такі принципи мають універсальний чи цивілізаційний

\footnotetext{
4 Цитоване формулювання засвідчує, по-перше, аксіологічне походження європейських стандартів, закріплених як принципів $i$ заснованих на спільних ідеалах, і по-друге, їх історичний зв'язок із сферою прав людини і водночас значно ширше змістовне охоплення.
} 
характер, формувалися вони у певній окремій національній системі права чи, можливо, паралельно у декількох таких системах. Лише згодом, після усвідомлення їх спільного значення для держав, об'єднаних у тій чи іншій міжнародній організації, вони закріплюються у міжнародно-правових актах.

Поряд з міжнародними договорами існує низка міжнародних документів, які містять правові стандарти, проте формально не мають зобов'язального характеру, властивого договорам. Це акти міжнародних організацій, які сьогодні прийнято відносити до так званого «м'якого права» (див., наприклад, [19; 20]).

«М'яке право» $є$ відносно новим феноменом; встановлені такими актами міжнародні стандарти є породженням міжнародного права XX ст. Природа норм «м'якого права» неоднорідна, хоча це, як правило, положення, що містяться в актах, прийнятих органами міжнародних організацій, зокрема ООН, Міжпарламентського союзу, Ради Європи, оБСЄ та ін., а також утвореними ними органами (організаціями), як Європейська комісія «За демократію через право» (Венеціанська комісія), Бюро з демократичних інституцій і прав людини (БДІПЛ), Група держав проти корупції (GRECO) і низка інших. Зазначені акти не підлягають ратифікації державами-членами.

Існують різні підходи до розуміння норм, що встановлюються актами «м'якого права». Досить поширена точка зору, яка взагалі не вважає стандарти, що містяться у подібних актах, нормами права; їм приписується обмежена роль зразків для національного законодавства, однак вважається, що вони не можуть бути складовою частиною внутрішньодержавного законодавства. Свого часу Конституційний трибунал Польщі відмовився визнавати Кодекс належної практики у виборчих справах, прийнятий Венеціанською комісією, за критерій контролю виборчого законодавства, оскільки він не є зобов'язальною міжнародною угодою (див. [21, s. 172]).

Однак завдяки високому авторитету відповідних міжнародних організацій навколо таких ак-

\footnotetext{
${ }^{5}$ Визнання за нормами «м'якого права» заохочувального (а не чисто рекомендаційного) характеру підкреслює їх значення як регулівних (тобто таких норм, які встановлюють бажане правило поведінки і стимулюють його дотримання).

6 Копенгагенський документ є прикладом недоговірної міжнародної домовленості, яка набула великого міжнародного авторитету і окремі положення якої реалізуються у зобов'язальних міжнародно-правових актах (див. [20, р. 501-502]).
}

тів формується атмосфера «спонукання» до їх дотримання державами - членами цих організацій. Через це науковці визнають правовий (хоча і специфічний) характер норм «м'якого права». Так, О. Київець надає «м'якій» нормі «основну функцію, притаманну будь-якій правовій нормі - регулюючу», однак відносить такі норми до заохочувальних ${ }^{5}$ [5, с. 388]. Як зазначають експерти Ради Європи, «м'яке» право відіграє величезну роль у тлумаченні стандартів, які мають юридично обов'язкову силу, або й навіть у формуванні міжнародного звичаєвого права» [22, с.18].

Яскравим прикладом є сприйняття у міжнародному праві Загальної декларації прав людини ООН 1948 р., яка не є зобов'язальним міжнародним договором. Однак сьогодні Декларація фактично розглядається як документ високої юридичної сили (на рівні із правовим звичаєм), як правова основа системи міжнародного права прав людини. Подібна еволюція відбулася із Заключним (Гельсінським) актом Наради з безпеки і співробітництва в Європі 1975 р. Наслідком зростання авторитету базового документа НБСЄ стало надання подібної авторитетності й іншим документам цієї організації, зокрема документа Копенгагенської наради з людського виміру НБСЄ 1990 р. [23]. Хоча цей акт кваліфікується як «політично, а не юридично зобов'язальний, оскільки він не підлягає формальній процедурі ратифікації» [24, с. 286], проте він відіграє важливу роль ${ }^{6}$, зокрема при оцінці якості виборів міжнародними місіями спостереження під егідою ОБСЄ/БДІПЛ. Поступове набуття правового значення подібними актами, які первинно мають політичний характер, дозволяє кваліфікувати ці акти як джерела міжнародних правових стандартів, що ними встановлені.

Таким чином, стандарти, встановлені як міжнародними договорами, так і актами «м'якого права», $\epsilon$ правовими нормами, хоча й різного способу дії (чи, можливо, різної юридичної сили). Це дозволяє стверджувати про наявність принаймні двох категорій правових положень, що виражають зміст міжнародних правових стандартів - зобов'язальних, закріплених у міжнародно-правових договорах, що підлягають ратифікації (приєднанню) з боку держав, та авторитетних, встановлених документами, прийнятими впливовими міжнародними організаціями. Однак як зобов'язальні, так і авторитетні положення мають правовий характер і змушують (хоча й різними засобами) відпо- 
відні держави дотримуватися їх силою міжнародного правового порядку.

Важливою загальновизнаною рисою міжнародно-правових стандартів $\epsilon$ їх «мінімальний» характер; він прямо зазначається в основних зобов'язальних міжнародно-правових актах (див. статтю 5 Міжнародного пакту про громадянські та політичні права, статтю 17 Конвенції про захист прав людини і основоположних свобод). Цю рису підкреслюють і правознавці: «міжнародні стандарти прав людини встановлюють власне «мінімальний стандарт», є «мінімально допустимим консенсусом»; вони не лише закріплюють перелік загальновизнаних прав, але й фіксують їх певний необхідний обсяг, мінімальний рівень, на якому останні мають реалізовуватись» [4]. За зауваженням М. Смоковича, «міжнародний стандарт $\epsilon$ незнижуваним мінімумом» $[25$, с. 56].Дійсно, саме мінімальність вимог щодо дотримання певного необхідного рівня, власне, й обгрунтовує можливість застосування терміна «стандарт» до таких положень: те, що не відповідає стандарту («нижче» від стандарту), тобто $є$ «нестандартним», визнається неприпустимим.

Зауважимо водночас, що цілком прийнятними $є$ відхилення від такого нормативно-обов'язкового «мінімуму» з метою його перевищення, більш повної реалізації відповідного принципу національними правовими нормами. Випадки таких відхилень існують і в національному виборчому праві, зокрема, щодо обсягу права голосу в рамках стандарту загального виборчого права.

У цьому контексті необхідно звернути увагу на певну суперечність між розумінням стандарту як мінімально припустимої вимоги та визнанням того, що за своєю роллю міжнародні правові стандарти, по суті, $\epsilon$ правовими принципами, тобто мали б бути певною мірою «ідеальними», якнайвищими вимогами. Розв'язання цієї суперечності слід шукати у способі розкриття загальновизнаного змісту такого стандарту-принципу, склад і розуміння вимог якого підлягають додатковому тлумаченню.

Так, наприклад, принцип загального виборчого права $є$ міжнародним виборчим стандартом; однак його зміст допускає певні межі тлумачення. Мінімальні вимоги цього принципу, встановлені міжнародним виборчим стандартом, допускають певні обмеження щодо володіння правом голосу на виборах (див., наприклад, [24, с. 144]); водночас ідеальний зміст цього принципу стимулює раціональне розширення кола суб'єктів права голосу, у тому числі з подоланням деяких обмежень, визнаних, взагалі кажучи, припустимими. Зокрема, не можна вважати порушенням стандарту-принципу загального виборчого права зниження в Австрії виборчого цензу щодо права голосу до 16 років, надання права голосу недієздатним у Швеції чи безумовне збереження права голосу ув'язнених в Україні та деяких інших країнах.

Зміст і структура міжнародних правових стандартів. Вивчення змісту положень зобов'язальних міжнародно-правових документів, що містять правові стандарти, демонструє максимально абстрактне формулювання відповідних положень, без їх змістовної конкретизації. Виборчі стандарти у цьому сенсі особливо лаконічні, оскільки мають вигляд принципів-назв.

Поглиблення процесів глобалізації та європейської інтеграції, посилення уваги до єдиного розуміння спільних цивілізаційних цінностей, зокрема демократії, стимулювали значну увагу до проблем наповнення основних принципів виборчого права, проголошених як зобов'язальні виборчі стандарти. Загальний, максимально абстрактний рівень формулювання стандартів, хоча й не знижує рівня їх зобов'язальності, тим не менше вимагає спільного чи принаймні узгодженого розуміння їх змісту ${ }^{7}$. Саме тут виявляється істотна роль «авторитетних» джерел стандартів, виражених приписами «м'якого права»: на них покладається важлива функція забезпечення загальновизнаного змісту принципів-назв, їх належного відображення у національному законодавстві у відповідності до основних суспільно-правових цінностей конституціоналізму (див. [27, с. 82]) та єдності праворозуміння у відповідній сфері регулювання. Сутність такого стандарту-принципу має розкриватися, як правило, «спектрально» [18, с. 65-66], через систему менш абстрактних вимог-складових, які наповнюють принцип-назву більш конкретним змістом, визначають спосіб його розуміння і відкривають практичні можливості його застосування як регулятора. Зазначена функція розкриття змісту стандартів-принципів реалізується на практиці принаймні двома можливими шляхами.

\footnotetext{
За слушним зауваженням М. Теплюка, термінологічний збіг конституційних формулювань з міжнародно-правовими документами ще не доводить $і$ не гарантує їх інтерпретаційно-змістову однозначність [28, с. 68]. Така проблема особливо гостра стосовно проголошення принципів-назв (наприклад, у ст. 71 Конституції України).
} 
Перший шлях полягає у виданні акта «м'якого права», який тлумачить зміст принципів, викладених у зобов'язальному акті. Цим шляхом пішов, наприклад, Комітет ООН з прав людини: у 1996 р. він видав «Загальний коментар статті 25 Міжнародного пакту про громадянські та політичні права» [29], в якому надав поширене автентичне тлумачення положень зазначеної статті у контексті вимоги звітів (доповідей) про дотримання державами - сторонами Пакту його положень.

Інший шлях реалізований у практиці Венеціанської комісії. Документи, які містять виклад узагальнених Комісією європейських стандартів щодо відповідних галузей національного конституційного права, - «кодекси належної практики» (Code of Good Practice) - складаються з двох частин: керівних принципів (guidelines) та пояснювальної доповіді (explanatory report, explanatory memorandum). Перша з цих частин формулює стандарти-принципи та вимоги, що належать до його складу і визначають його загальний зміст; стосовно виборчих стандартів необхідність такого викладу викликана неявним способом закріплення цих принципів у диспозиції статті 3 Першого протоколу до Конвенції про захист прав людини та основоположних свобод. Друга частина такого документа $\epsilon$ поширеним коментарем зазначених керівних принципів, яка надає спільне (загальновизнане) тлумачення цих основоположних засад і їх складових вимог та гарантій їх дотримання, а також пропонує зразки «належної практики» щодо їх реалізації з досвіду різних європейських держав. У зв'язку з цим підкреслимо важливе значення першого із таких актів - Кодексу належної практики у виборчих справах ${ }^{8}$ [26], визнаного еталонним документом Ради Європи у сфері європейського виборчого доробку, який викладає сутність і загальновизнаний зміст основних принципів виборчого права разом із рекомендаційними положеннями, що описують зразки «належної практики» їх реалізації.

Подібний зміст має Декларація про критерії вільних і чесних виборів Міжпарламентського союзу [13], яка не лише проголошує ці два фундаментальні принципи демократичних виборів, але й

\footnotetext{
8 Український переклад Кодексу див. [24, с. 143-176].

9 Дж. Гудвін-Джіл вказує, що Декларація Міжпарламентського союзу не є зобов'язальною для держав, проте підкреслює впливовість (authority) її положень насамперед завдяки міжнародному праву та практиці демократичних держав [30, р. 3].
}

викладає їх достатньо детальний зміст через взаємозв'язок з іншими принципами виборчого права, а також вимоги щодо державної політики у цій сфері ${ }^{9}$.

Отже, формулювання основних галузевих принципів як міжнародних стандартів може здійснюватися «переконливими» джерелами у формі м'якого права. Характерною особливістю останніх є вихід за межі проголошення принципів, що передбачає, по-перше, надання загальноприйнятого (в межах спільноти держав - членів відповідної міжнародної організації) тлумачення змісту того чи іншого принципу; по-друге, опис відповідної практики застосування (позитивної реалізації) такого принципу. Можна стверджувати, що «авторитетні» стандарти доповнюють проголошені зобов'язальними актами основні галузеві принципи спільним розумінням їх змісту, встановлюють мінімально припустимий рівень дотримання стандартів і зразки (еталони) для наслідування щодо розуміння (тлумачення) і застосування цих принципів у практиці держав-членів.

У межах системи європейських правових стандартів, основу якої складає Конвенція про захист прав людини та основоположних свобод, існує ще одна характерна група джерел правових стандартів, що виконує ту ж функцію, що й джерела м'якого права, - тлумачення основних стандартів (принципів), встановлених Конвенцією, та оцінку практики ії реалізації державами-учасниками. Зазначені джерела - це практика (рішення) Європейського Суду з прав людини (ЄСПЛ), специфічного, якщо не унікального, наднаціонального юрисдикційного органу. Закон України «Про виконання рішень та застосування практики $\epsilon_{\mathrm{B}}$ ропейського суду з прав людини» наближає акти ЄСПЛ за їх юридичною силою до зобов'язальних міжнародно-правових актів, надаючи правовим позиціям Суду статусу джерел національного права.

Отже, роз'яснення загальновизнаного розуміння змісту стандартів-принципів, суті та змісту їх мінімальних вимог здійснюється на міжнародному рівні актами «м'якого права». На основі так встановленого загальновизнаного їх розуміння оцінюється ступінь дотримання зазначених принципів. Стосовно визначення змісту встановлених стандартів-принципів слід вважати формулювання «авторитетних» правових актів невід'ємною складовою зобов'язальних стандартів; саме вони визначають ті мінімальні вимоги, які формально 
| HAYKOBI CTATTI

встановлюються зобов'язальними стандартами. Це дозволяє зробити висновок про те, що окремий стандарт як цілість може бути встановлений кількома положеннями різних міжнародно-правових актів, які ще й часто мають різну правову природу («жорстке» чи «м'яке» право) та різну юридичну силу.

Проте зазначені міркування не можуть бути поширеними на ту частину правових стандартів, встановлених актами «м'якого права», яка визначає зразки «належної практики». Такі зразки часто виходять за межі мінімальних вимог і виконують роль ілюстрації застосування стандартів-принципів у тому їх розумінні, яке визначається загальновизнаним їх тлумаченням. Саме до цієї групи стандартів відноситься повною мірою розуміння стандарту як правової категорії, що визначає орієнтири для розвитку норм, але не встановлює при цьому обов'язкових приписів. У цій сфері велику роль відіграють конкретні суспільно-політичні обставини відповідної держави та контекст її національної системи права (у тому числі наявність чи відсутність відповідних звичаїв і традицій), що знаходить своє вираження у концепції «поля розсуду» (margin of appreciation) конкретної держави, розвинутої у практиці Європейського суду 3 прав людини. Стосовно виборчих стандартів, закріплених у статті 3 Першого протоколу, зазначена концепція детально аргументована Судом у рішенні у справі «Матьє-Моен і Клерфе проти Бельгії» [15] і повторена у низці інших рішень.

Як типові приклади міжнародних документів м'якого права, які мають рекомендаційно-ілюстративне значення у сфері виборчого права, можна навести висновки Венеціанської комісії як щодо узагальнення практики різних держав, так і щодо законодавчих актів чи законопроектів конкретних держав, часом спільно з БДІПЛ (див., наприклад, [24, с. 415-460; 31, с. 295-321]). Іншими прик- ладами таких актів можуть слугувати звіти місій ОБСЕ/БДІПЛ зі спостереження за виборами.

Отже, насамперед слід визнати існування групи міжнародних правових стандартів, які характеризуються обов'язковістю та мінімальним характером встановлених правових вимог. Це стандарти, встановлені міжнародно-правовими договорами, які мають вигляд проголошення галузевих чи інституційних принципів. Невід'ємну частину цих стандартів складають положення актів міжнародних організацій, які надають загальновизнане розуміння проголошених принципів, що має «переконливий» («авторитетний»), тобто близький до зобов'язального характер; сюди ж належать правові позиції Європейського суду з прав людини у тій частині, у якій вони надають судове тлумачення положень зобов'язальних стандартів-принципів. Враховуючи нерозривний змістовний зв'язок цих видів положень, необхідно розглядати їх (тобто положення як зобов'язальних, так і авторитетних міжнародно-правових актів, а також відповідні правові позиції ЄСПЛ, які стосуються одного принципу права) як єдиний міжнародно-правовий обов'язковий стандарт.

Інший рівень складають стандарти, викладені у різних актах «м'якого права» у вигляді зразків чи прикладів «належної практики». Ці стандарти, хоча й пов'язані з відповідними обов'язковими стандартами-принципами, є рекомендаційними і не мають зобов'язального та мінімального характеру. Відхилення від таких рекомендаційних стандартів-практик визначаються визнаним за кожною державою полем власного розсуду та розглядаються як припустимі тою мірою, якою вони не порушують загальновизнаного мінімального змісту обов'язкового стандарту-принципу.

Зазначені висновки щодо структури міжнародного правового стандарту (у тому числі виборчого стандарту) можна зобразити у вигляді схеми:

\begin{tabular}{|c|c|c|}
\hline Вид акту & Зміст положень & Ступінь зобов'язальності : \\
\hline $\begin{array}{l}\text { Ратифіковані } \\
\text { міжнародно-правові договори }\end{array}$ & Принцип-назва & Обов'язковий стандарт \\
\hline $\begin{array}{l}\text { Акти міжнародних організацій } \\
\text { (акти «м'якого права») } \\
\text { та рішення ЄСПЛ }\end{array}$ & 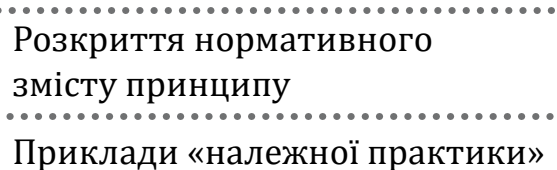 & Рекомендаційний стандарт \\
\hline
\end{tabular}


Отже, міжнародний виборчий стандарт - це певний принцип об'єктивного виборчого права, сформульований у міжнародно-правовому акті зобов'язального або авторитетного характеру, разом із загальновизнаним викладом його змісту, а також зразки заходів («належної практики»), що застосовуються різними державами, з метою якнайповнішої реалізації цього принципу у виборчому законодавстві та практиці проведення виборів.

Роль міжнародних стандартів у національномуправідержави. Дослідники визнають, що міжнародні правові стандарти чинять істотний вплив на відповідне національне законодавство держав. При вивченні конкретних галузевих (зокрема, виборчих) стандартів часто, однак, залишається поза увагою спосіб, яким чиниться такий вплив.

Будучи сформованими у межах системи міжнародного права, міжнародно-правові стандарти найчастіше розглядаються як положення, що зобов'язують державу як суб'єкта міжнародних правовідносин. Однак чи можуть положення міжнародного права бути безпосередньо застосованими при регулюванні внутрішньодержавних правовідносин різних суб'єктів, а отже, чи зобов'язують таких суб'єктів? Окремі науковці, розглядаючи проблему міжнародних галузевих стандартів, обходять це питання, відносячи до джерел виборчого права України акти міжнародного права, які стосуються організації та проведення виборів і реалізації виборчих прав, однак не даючи відповіді на питання, яким чином норми міжнародного права регулюють суспільні відносини щодо організації і проведення виборів (тобто внутрішні правовідносини) у конкретній державі.

Проте, розглядаючи проблему відповідності національного законодавства у певній галузі міжнародно-правовим стандартам, не можна ігнорувати питання про спосіб, яким забезпечується вплив міжнародних стандартів на правовідносини, що виникають у внутрішньому житті конкретної держави. Зазначена проблема є окремим випадком загальної проблеми співвідношення міжнародного і національного (внутрішньодержавного) права, розв'язання якої фахівці шукають на основі відомих правових доктрин - моністичної чи дуалістичної, у межах яких існують різні більш конкретні теорії. Є. Танчев стверджує: «Відповідно до панівної у Європі моністичної системи, міжнародний договір стає інтегральною частиною національного права після ратифікації. Якщо країна сприйняла дуалізм, імплементація договірних зобов'язань може здійснюватися не через ратифікацію, а через прийняття спеціального закону чи шляхом включення положення до чинного національного законодавства» [3, p. 27].

Сучасні правознавці дотримуються різних поглядів щодо впливу міжнародних правових стандартів на національне право держави. На думку М. Баймуратова, проникнення двох сфер права міжнародного і внутрішньодержавного - взаємне: «національне право держави i, насамперед, iї конституційне право впливає на формування міжнародного й інтеграційного права, передаючи йому для подальшої нормативізації свої раніше абсолютні об'єкти конституційно-правового регулювання», і водночас «національне право держави i, насамперед, її конституційне право зазнає серйозного впливу міжнародного й інтеграційного права, тобто воно інтернаціоналізується» [2, с. 46]. Таким чином, подолання розмежування міжнародного права і національного права держав в умовах глобалізації стає щораз більш помітним.

Прийнято вважати, що у Конституції України відображена моністична доктрина, яка передбачає безпосередній вплив міжнародного права на національне. Проте стаття 9 Конституції відносить до національного законодавства тільки «чинні міжнародні договори, згода на обов'язковість яких надана Верховною Радою України». Стаття 9 Закону «Про міжнародні договори України» передбачає застосування таких договорів у порядку, передбаченому для норм національного законодавства, та встановлює пріоритет (вищу юридичну силу) правил, встановлених міжнародним договором, порівняно з правилами, передбаченими відповідним актом законодавства України. Розуміння статті 9 Конституції, відповідно до якого передбачається пріоритет норм міжнародного договору перед положеннями актів національного законодавства (за винятком самої Конституції), було сформульоване ще у 1996 р., коли постанова Пленуму Верховного Суду України «Про застосування Конституції України при здійсненні правосуддя» вказала, що «суд не може застосувати закон, який регулює правовідносини, що розглядаються, інакше як міжнародний договір» [32].

Однак описані позиції стосуються лише ратифікованих міжнародних договорів. Конституція залишає неврегульованими навіть питання статусу 
норм, що містяться у правових міжурядових угодах (які не підлягають ратифікації); тим більше це стосується актів «м'якого права».

Не вникаючи глибше у проблему співвідношення міжнародного та національного права, зауважимо, що обидві доктрини (моністична і дуалістична) передбачають потребу імплементації міжнародно-правових норм у національне право, хоча відрізняються за мотивацією: за дуалістичною концепцією держава робить це з власної волі і лише через нормативні акти, тоді як за моністичною - виконуючи свої зобов'язання, і не лише у сфері нормотворення, але й правозастосування.

Положення міжнародного права (зокрема, міжнародно-правові стандарти) можуть бути імплементовані у національне право трьома способами. Основними серед них є законодавчий - через прийняття відповідних нормативно-правових актів (насамперед законів, але також і інших, підзаконних актів) - та правозастосовний - через застосування відповідних положень у юрисдикційній діяльності. Водночас не можна ігнорувати також третій спосіб - безпосереднє практичне застосування (врахування при визначенні власної поведінки) вимог міжнародно-правових стандартів усіма суб'єктами (у тому числі невладними), яких вони стосуються. Це означає прямий вплив міжнародних стандартів на формування поведінки суб'єктів права. Зокрема, при проведенні виборів важливим $\epsilon$ дотримання міжнародних виборчих стандартів усіма суб'єктами виборчого процесу (виборцями, кандидатами, партіями, спостерігачами) та іншими суб'єктами, які вступають у виборчі правовідносини (зокрема, засобами масової інформації, журналістами, інформаційними агентствами, іншими розповсюджувачами реклами). Для такого дотримання перші два шляхи імплементації забезпечують відповідні умови, однак організаційно воно має самостійне значення.

Законодавча імплементація відіграє основну роль у реалізації міжнародно-правових стандартів; ця роль визначається місцем законів у формуванні й функціонуванні правової системи України, яка належить до континентальної правової сім'ї. У цьому контексті міжнародні правові стандарти чинять вплив на зміст національних законів, відіграючи роль принципів відповідних галузей права на наднаціональному рівні, ще на етапі формування відповідної законодавчої бази, тобто раніше, аніж вони будуть зафіксовані у національному нормативно-правовому акті.
Правозастосовна імплементація випливає із розуміння міжнародного договору (основного джерела обов'язкового правового стандарту) як такого, що переносить зобов'язання держави щодо дотримання договору на зобов'язання органів держави щодо застосування положень міжнародного договору у їх внутрішньодержавній діяльності, насамперед при вирішенні справ судами. Такий обов'язок покладається не лише на суди, але й на інші юрисдикційні органи, зокрема у виборчому процесі - на виборчі комісії, які здійснюють повноваження забезпечення законності виборчого процесу, захисту прав і законних інтересів громадян та інших суб'єктів виборчого процесу, у тому числі (однак не лише) при розгляді виборчих спорів. Внаслідок цього правозастосовний спосіб імплементації, по суті, стимулює також дотримання міжнародних стандартів у діяльності громадян, політичних партій, інших суб'єктів виборчих правовідносин, оскільки порушення цих стандартів з їх боку можуть бути оскаржені у судовому чи адміністративному порядку.

Визнання зобов'язальних міжнародних стандартів принципами права дозволяє говорити про додатковий, досі не вивчений механізм прямого застосування цих стандартів у національній системі права, який базується на уявленні про принципи права як окремий вид джерел права (див. $[18$, с. 52]). Такі принципи, тим більше зафіксовані у міжнародно-правових документах, можуть використовуватися у правозастосовній діяльності та практиці без спеціальної законодавчої імплементації.

Імплементація міжнародно-правових стандартів у національне законодавство та правозастосовну діяльність, незалежно від прийнятої доктрини співвідношення міжнародного і національного права, de facto визнає пріоритет міжнародно-правових норм, оскільки саме у відповідність з останніми приводиться правова система держави.

Отже, кінцевою метою імплементації (як законодавчої, так і правозастосовної) $є$ практичне застосування (дотримання) міжнародно-правових стандартів у конкретних правовідносинах, що регулюються національним правом, усіма їх суб'єктами.

Описані вище способи імплементації безпосередньо стосуються міжнародно-правових стандартів, що встановлені зобов'язальними міжнародними договорами. Проте, як уже зазначалося, 
такі стандарти мають вигляд абстрактно сформульованих основних галузевих принципів. Тому їх імплементація у національне законодавство, правозастосування і практику вимагає чіткого усвідомлення змісту відповідних принципів, який визначається переконливими актами, що належать до «м'якого права». Саме обидві складові обов'язкового стандарту (зобов'язальна й авторитетна) у єдності й повинні визначати зміст норм національного права, якими здійснюється імплементація міжнародних стандартів у національне законодавство, а також тлумачення таких норм у правозастосовній діяльності, зокрема Конституційним Судом України. Таким чином, імплементації підлягають обов'язкові стандарти у цілому. Закріплення тих складових обов'язкового міжнародно-правового стандарту, які викладені в актах «м'якого права», у національних нормативно-правових актах $€$ важливою та обов'язковою складовою імплементації міжнародних стандартів.

Водночас слід зауважити, що рекомендаційні стандарти типу «належної практики», які не є обов'язковими для держав і реалізуються у межах певного «поля розсуду», можуть бути імплементовані лише законодавчим шляхом. Формування правових позицій юрисдикційних органів, насамперед судів, на основі такого типу стандартів, не імплементованих у законодавство, може призвести до порушення деяких принципів - складових верховенства права (зокрема законності, юридичної визначеності та правової безпеки). У цьому полягає істотна відмінність рекомендаційних стандартів-практик від обов'язкових стандартів-принципів, сформульованих частково в актах м'якого права.

Законодавчий спосіб імплементації міжнародно-правових стандартів у національну систему права України відіграє основну роль. Адекватне відображення змісту основних принципів, який визначається як зобов'язальними міжнародно-правовими актами, так і авторитетними актами м'якого права, у положеннях національного законодавства гарантує обов'язок їх дотримання незалежно від способу праворозуміння відповідного

\footnotetext{
10 Дещо «знижений» рівень цього принципу у викладі Кодексу може бути пояснений тим, що європейська практика голосування допускає формуголосування за інших осіб - голосування за дорученням, визнану Кодексом за прийнятну.

11 Див., наприклад, Остаточний звіт Місії ОБСЕ/БДІПЛ зі сnостереження за позачерговими виборами до Верховної Ради Украӥни 2014 p. [33].
}

суб'єкта правозастосування. Зокрема, звіти Міжнародних місій спостереження за виборами ОБСЕ/ БДІПЛ звертають велику увагу передусім на відповідність міжнародним стандартам виборчого законодавства держави, і лише на цій основі - на реалізацію вказаних стандартів у практиці проведення виборів ${ }^{10}$. Невідповідність законодавства обов'язковим міжнародно-правовим стандартам означає порушення принципу верховенства права в аспекті невідповідності права і закону.

\section{Система міжнародних виборчих стандар-}

тів. У літературі можна зустріти різні погляди на систему міжнародних виборчих стандартів, їх перелік та підходи до їх класифікації (див., наприклад, [6, с. 68-72; 34, с. 316]). Різні переліки виборчих стандартів містять і міжнародно-правові акти.

У найбільш систематизованому вигляді європейські стандарти демократичних виборів викладені у згаданому вище Кодексі належної практики у виборчих справах [26], прийнятому Венеціанською комісією у 2002 р. і визнаному «еталонним документом» (reference document) Ради Європи та держав-членів, який покликаний надати єдину систему критеріїв для оцінки виборів у різних країнах при проведенні міжнародного спостереження. У цьому важливому для доктрини виборчого права акті, який увібрав у себе зміст як універсальних, так і європейських виборчих стандартів, закріплено основні виборчі стандарти-принципи, надано загальноприйняте для держав - членів Ради Європи розуміння їх змісту (що складає обов'язкову частину зазначених стандартів), а також наведено низку положень, які містять виклад рекомендаційних стандартів, що входять до складу зазначених основних стандартів-принципів і спрямовані на їх належну реалізацію.

Перша частина Кодексу «Керівні принципів щодо виборів» у її Розділі I містить виклад шести «засад виборчого права: загальне та рівне виборче право, вільні та прямі вибори, таємне голосування», а також вимогу регулярного проведення виборів.

Проте у цьому розділі сформульований ще один важливий виборчий стандарт - принцип особистого голосування. I хоча Кодекс не піднімає його на той же рівень, що й попередні шість принципів ${ }^{11}$, його значення підкреслене прямою вказівкою на нього у додатковому документі Венеціанської комісії - Декларації про участь жінок у виборах [24, c. 178]. 
| HAYKOBI CTATTI

Розділ II «Керівних принципів» присвячений умовам реалізації зазначених принципів. Проте із змісту цих умов випливають деякі важливі положення, які можна вважати неявним формулюванням ще одного базового стандарту. Так, сукупність положень, названих «процесуальними гарантіями» - організація голосування безстороннім органом, спостереження за виборами, існування дієвої системи оскаржень - разом із вимогами боротьби з порушеннями на виборах фактично складають основу змісту принципу чесних виборів.

Нагадаємо, що принцип чесних виборів як міжнародний виборчий стандарт проголошений і роз'яснений Декларацією Міжпарламентського союзу про критерії вільних і чесних виборів [13]; він також закріплений у вигляді низки положень у Копенгагенському документі НБСЄ 1990 р. [23].

При розгляді стандартів, викладених у Кодексі належної практики у виборчих справах, слід згадати також вимогу стабільності виборчого законодавства, згідно з якою основні елементи виборчого закону не можна переглядати менш як за рік до проведення виборів. Додатковий документ Венеціанської комісії - Інтерпретативна декларація про стабільність виборчого законодавства [24, с. 177] - кваліфікує відповідне положення як принцип, який, проте, «не має переваги перед іншими принципами Кодексу». Хоча зміст цього принципу дещо відрізняється за своєю природою від стандартів-принципів, розглянутих попередньо (він стосується не змісту положень виборчого права, а практики прийняття і перегляду виборчого законодавства, тобто особливостей відповідного законодавчого процесу), однак значення цієї вимоги для належного проведення виборів важливе. Тому його слід відносити до основних виборчих стандартів-принципів.

Слід визнати, що у тексті Кодексу не знайшов свого прямого відображення принцип справжніх (альтернативних) виборів, проголошений основними зобов'язальними міжнародно-правовими актами, зокрема, статтею 25 Міжнародного пакту про громадянські та політичні права, та роз'яснений Загальним коментарем Комітету ООН з прав людини та Декларацією Міжпарламентського союзу про критерії вільних і чесних виборів. Проте увесь текст Кодексу належної практики у виборчих справах проникнутий духом необхідності політичного плюралізму, що за своєю суттю виключає можливість проведення «виборів без вибору»основної антитези справжніх виборів.

Підсумовуючи, пропонуємо перелік основних міжнародних виборчих стандартів-принципів (у формі принципів-назв), складений на підставі міжнародно-правових актів:

1. Принцип прямих виборів.

2. Принцип періодичних виборів.

3. Принцип загального виборчого права.

4. Принцип рівного виборчого права.

5. Принцип вільних виборів.

6. Принцип справжніх виборів.

7. Принцип чесних виборів.

8. Принцип таємного голосування.

9. Принцип особистого голосування.

10. Принцип стабільності виборчого законодавства.

Усі перелічені стандарти-принципи відіграють визначальну роль для забезпечення проведення дійсно демократичних виборів. За своїм змістом вони охоплюють усі часткові виборчі стандарти, як викладені у різних міжнародно-правових актах. Проте їх місце у системі принципів виборчого права неоднакове. Так, перші два з наведених принципів $€$ фактично конституційно-правовими принципами представницької демократії, оскільки мають більш загальний за своїм змістом характер. Безпосередньо до галузі виборчого права належать сім принципів: загального і рівного виборчого права, справжніх, вільних і чесних виборів, таємного та особистого голосування; при цьому два останні $\epsilon$, по суті, принципами інституту голосування - одного з основних інститутів галузі виборчого права. Як уже зазначалося, останній із наведених принципів має специфічне значення для законодавчого процесу.

Таким чином, міжнародні виборчі стандарти виступають в основному як галузеві принципи об’єктивного виборчого права і містять як виклад обов'язкового змісту відповідних основоположних вимог, так і рекомендації щодо їх реалізації. У цьому контексті доцільно нагадати визначення М. І. Козюброю принципів права як виразу «правових тенденцій, які розвиваються в глибинах нормативно розвинутого суспільного життя» [35, с. 6]. Саме такими тенденціями, що сформувалися у процесі розвитку виборчого права, зразками, які мають бути забезпечені, виступають міжнародні стандарти, сформульовані у вигляді принципів виборчого права. Такі стандарти повинні складати систему міні- 
мальних вимог як до національного виборчого законодавства, так і до правозастосовної практики проведення виборів, без дотримання яких немає сенсу говорити про існування демократичних виборів.

Міжнародні правові стандарти виконують роль визначальних засобів досягнення правової єдності держав, які поділяють спільні цінності і глибинні правові принципи. У такий спосіб здійснюється поступове формування європейського правового простору, який базується на уніфікації національного права держав - членів Ради Європи шляхом визнання й імплементації європейських правових стандартів. У цьому контексті формується нове правове явище - галузі внутрішньодержавного права без національного атрибутування. Саме тому можна говорити, наприклад, про «європейський виборчий доробок» - галузь вибор- чого права, яка, як цілісна система норм, є спільною для багатьох європейських національних систем права.

Україна зробила істотні кроки у плані реалізації європейських стандартів демократичних виборів шляхом імплементації відповідних норм у вітчизняне виборче законодавство, хоча цей процес все ще не завершений. Водночас значно більше застережень виникає щодо дотримання цих стандартів у процесі застосування законодавства під час проведення виборів, як це засвідчується, зокрема, звітами місій міжнародного спостереження. В Україні продовжують існувати проблеми як належного розуміння природи, змісту і статусу європейських виборчих стандартів, а отже, і принципів виборчого права, так і сумнівна практика певного ігнорування зазначених стандартів, що має ознаки правового нігілізму.

\section{СПИСОК ВИКОРИСТАНИХ ДЖЕРЕЛ / REFERENCES}

1. Тіунов О. Правові стандарти якзасіб регулювання міжнародних та внутрішньодержавних відносин // Міжнародне право. - 2012. - № 1. - С. 10-26.

2. Баймуратов М. О., Алмохаммед М. А. Конституційне право і національна правова демократична державність // Вісник Центральної виборчої комісї̈. - 2015. - № 1 (31). - C. 38-49.

3. Tanchev E. Attracting Electoral Participation through Establishing International and European Legal Standards of Democratic Elections. Enhancing Participation in Elections: 6th European Conference of Electoral Management Bodies (The Hague, 30 Nov. 1 Dec. 2009) and Every Voter Counts: 7th European Conference of Electoral Management Bodies (London, 22-23 June 2010). Selected Reports / CDL-EL(2011)003. - Strasbourg: Council of Europe, 2011. — P. 14-45.

4. Рабінович П., Венецька О. Міжнародні стандарти прав людини: загальні ознаки, поняття // Юридичний вісник України. - 2012. - 13-19 груд. (№ 49 (910)). - С. 6.

5. Київець О. В. У пошуках міжнародного права: переосмислюючи джерела: монографія / О. Київець. - Кам'янецьПодільський: Оіюм, 2011. - 480 с.

6. Баймуратов М. О., Кофман Б. Я. Міжнародні виборчі стандарти: правова природа, змістовна та системна характеристика, актуальні питання імплементації в законодавство України: монографія / ред. Ю. о. Волошин. Суми: Університетська книга, - 2012. - 230 с.

7. Statute of the Council of Europe. [Electronic resource]. - Access mode : http://conventions.coe.int/Treaty/en/Treaties/ Html/001.htm (Last accessed: 28.08.2018).

8. Europe's Electoral Heritage (CDL(2002)007rev). [Electronic resource]. - Access mode : https://www.venice.coe.int/web forms/documents/?pdf=CDL(2002)007rev-e (Last accessed: 28.08.2018).

9. Козюбра М. Принципи права: методологічні підходи до розуміння пироди та класифікації в умовах сучасних глобалізаційних трансформацій // Право Украӥни. — 2017. - № 11. - C. 142-164.

10. Загальна декларація прав людини. [Електронний ресурс]. — Режим доступу : http://zakon.rada.gov.ua/laws/show 1995_015 (дата звернення 28.08.2018).

11. Повышение эффективности принципа периодических и подлинных выборов. Резолюция ГА ООН № $46 / 137$ (17 декабря 1991 2.). [Электронный ресурс]. — Режим достуnа : http://www.un.org/en/ga/search/view_doc.asp?symbol=A/ RES/46/137\&Lang=R (дата обращения 28.08.2018).

12. Міжнародний пакт про громадянські і політичні права. [Електронний ресурс]. — Режим доступу : httр://zakоп. rada.gov.ua/laws/show/995_043 (дата звернення 28.08.2018). 


\section{| HAУKOBI CTATTI}

13. Declaration on Criteria for Free and Fair Elections. Unanimously adopted by the Inter-Parliamentary Council at its 154th session (Paris, 26 March 1994). [Electronic resource]. — Access mode : http://www.ipu.org/Cnl-e/154-free.htm (Last accessed: 28.08.2018).

14. Протокол до Конвенції про захист прав людини і основоположних свобод // Право України. — 2010. — № 10. — C. 225-226.

15. Case of Mathieu-Mohin and Clerfayt v. Belgium / European Court for Human Rights. Judgment of 2 March 1987. [Electronic resource]. - Access mode : http://hudoc.echr.coe.int/eng?i=001-57536 (Last accessed: 28.08.2018).

16. Європейська хартія місцевого самоврядування // Офіційний вісник Украӥни. - 2013. — № 39. - С. 1418.

17. Серьогіна С. Європейські стандарти виборів і виборче законодавство України // Вісник Центральної виборчої комісії. - 2007. - № 1(7). - С. 38-44.

18. Ключковський Ю. Б. Принципи виборчого права: доктринальне розуміння, стан та перспективи законодавчої реалізації в Україні: монографія / Ю. Б. Ключковський. - К.: Ваіте, 2018. - 908 с.

19. Київець О. Феномен м'якої норми міжнародного права у діяльності міжнародних інституцій // Наукові записки Інституту законодавства Верховної Ради України. — 2012. — № 1. - С. 134-137.

20. Hillgenberg H. A Fresh Look at Soft Law // European Journal of International Law. - 1999. — Vol. 10. — No. 3. - P. 499-515.

21. Masternak-Kubiak M. Glosa do wyroku Trybunału Konstytucyjnego z dnia 3 listopada 2006 r. // Przegląd Seimowy. 2007. — № 2 (79). - S. 171-175.

22. Застосування міжнародних стандартів: посібник для національних спостерігачів за виборами ; ред. М.-К. фон Гумппенберг. - Страсбург; Тбілісі: Рада Європи, 2013. - 109 с.

23. Document of the Copenhagen Meeting of the Conference on the Human Dimension of the CSCE. [Electronic resource]. Access mode : http://www.osce.org/odihr/elections/14304?download=true (Last accessed: 24.03.2018).

24. Європейський демократичний доробок у галузі виборчого права: Матеріали Венеціанської Комісії ; пер. з англ. / за ред. Ю. Ключковського. - 3-є вид., випр. і доповн.: у 2-х част. - Київ: Логос, 2016. - Ч. 1. - 552 с.

25. Смокович М. І. Правове регулювання розгляду виборчих спорів: теоретичний і практичний аспекти: монографія / М. І. Смокович. - Київ: Юрінком Інтер, 2014. - 576 с.

26. Code of Good Practice in Electoral Matter: Guidelines and Explanatory Report (CDL-AD(2002)023rev2). [Electronic resource]. - Access mode: https://www.venice.coe.int/webforms/documents/?pdf=CDL-AD(2002)023rev2-e (Last accessed: 28.08.2018).

27. Бориславська О. М. Європейська модель конституціоналізму: системно-аксіологічний аналіз: монографія / О. М. Бориславська. - Харків: Право, 2018. - 384 c.

28. Принцип рівності у праві: теорія і практика:монографія / за заг. ред. Н. М. Оніщенко. — Київ: Юрид. думка, 2014. $380 \mathrm{c.}$

29. Загальний коментар статті 25 Міжнародного пакту про громадянські і політичні права / Комітет з прав людини ООН /Науково-практичний коментар Закону України «Про вибори Президента України» / за ред. Ю. Ключковського. - Київ: Парламентське вид-во, 2004. - С. 391-397.

30. Goodwin-Gill G.S. Free and Fair Elections. - New expanded ed. Geneva: Inter-Parliamentary Union, 2006. - XI. - 214 p.

31. Європейський демократичний доробоку галузі виборчого права: Матеріали Венеціанської Комісії: в 2-х част.; пер. з англ. / за ред. Ю. Ключковського. - 3-є вид., випр. і доповн. - Київ: Логос, 2016. - Ч. 2. - 472 с.

32. Постанова Пленуму Верховного Суду України від 1 листопада 1996 p. № 9 «Про застосування Конституції України при здійсненні правосуддя». [Електронний ресурс]. - Режим доступу : http://zakon.rada.gov.ua/laws/ show/v0009700-96 (дата звернення 28.08.2018).

33. Остаточний звіт Місії ОБСЕ/БДІПЛ зі спостереження за позачерговими виборами народних депутатів України 2014 p. [Електронний ресурс]. — Режим доступу: http://www.osce.org/uk/odihr/elections/ukraine/133441?down load=true (дата звернення 28.08.2018).

34. Тодика О. Виборче право України, інших країн СНД по формуванню парламентів в аспекті міжнародних виборчих стандартів і реалізації народовладдя / Reformy prawa wyborczego w Polsce i na Ukrainie / pod. red. P. Steciuka iJ. Buczkowskiego. - Przemyśl: Wyższa Szkoła Administracji a Zarzq̨dzania, 2004. - S. 314-324.

35. Козюбра М. I. Тенденції розвитку джерел прав України в контексті європейських правоінтеграційних процесів / Наукові записки Національного університету «Києво-Могилянська академія», 2004. — Т. 26. Юридичні науки. C. 3-8. 